\title{
Inhibitory Effect of Ultraviolet-inactivated Vesicular Stomatitis Virus on Initiation of DNA Synthesis in Cultured Chick Embryo Cells
}

\author{
By Y. YAOI AND M. AMANO \\ Biology Division, National Cancer Centre Research Institute, \\ Tsukiji 5-chome, Chuo-ku, Tokyo, Japan
}

(Accepted Io June I970)

\begin{abstract}
SUMMARY
The initiation of partially synchronized DNA synthesis was induced by medium replacement on stationary monolayer cultures of chick embryo cells. The synthesis of DNA started at $4 \mathrm{hr}$ and continued for $8 \mathrm{hr}$, and cells divided within ${ }_{5}$ to $\mathrm{I} 8 \mathrm{hr}$. The onset of DNA synthesis and subsequent cell division were inhibited by u.v.inactivated vesicular stomatitis virus if the cells were infected before the onset of DNA synthesis. In contrast, if the cells were infected during the $S$ phase, the continuing DNA replication and subsequent cell division were not inhibited. Thus the selective inhibition of the flow of $G_{\text {I }}$ cells to the $S$ phase was demonstrated in the cells infected with u.v.-inactivated vesicular stomatitis virus.
\end{abstract}

\section{INTRODUCTION}

Virus infection provides an important clue to regulatory mechanisms governing macromolecular synthesis in animal cells. When chick embryo cell monolayers are infected with u.v.-inactivated vesicular stomatitis virus (VSV), cellular RNA synthesis is rapidly inhibited, while cellular protein synthesis is not significantly inhibited (Yaoi, Mitsui \& Amano, I970 a). In these experiments, the stimulation of cellular DNA synthesis was observed after replacement of culture medium on uninfected cells, but was inhibited in infected cells.

The previous study was performed on cells in the exponential phase. The stimulation of cellular DNA synthesis by medium replacement was more clearly observed in cells in their stationary state, and synchronized cell populations were obtained by the medium replacement. In the present investigation, the inhibitory effects of u.v.-inactivated VSV on the onset of cellular DNA synthesis and on the ongoing DNA replication were studied in synchronized cell populations.

\section{METHODS}

Virus. U.v.-vesicular stomatitis virus (NEW JERSEY serotype, irradiated with ultraviolet light for $2 \mathrm{~min}$.) was prepared as described previously (Yaoi et al. 1970a). No infectivity was detected in the irradiated preparations.

Media and chemicals. Culture medium was composed of Eagle's minimal essential medium (Chiba Prefecture Serum Institute, Chiba, Japan), $5 \%$ calf serum (Chiba Prefecture Serum Institute), and supplemented with antibiotics and sodium bicarbonate. Foetal bovine serum was purchased from Microbiological Associates Inc., Bethesda. Radioactive compounds were $\left[{ }^{14} \mathrm{C}\right]$ thymidine-2 (O. I mc/o. I mg., New England Nuclear Corp., Boston), $\left[{ }^{3} \mathrm{H}\right]$ thymidine-methyl (5 $\mathrm{C} / \mathrm{mmole}$, New England Nuclear Corp.), $\left[{ }^{14} \mathrm{C}\right]$ uridine-2 (0. I mc/0.5 mg., New 
England Nuclear Corp.) and $\left[{ }^{14} \mathrm{C}\right]$ amino acids $\left(\left[{ }^{14} \mathrm{C}\right]\right.$ protein hydrolyzate, Radiochemical Centre, Amersham, Buckinghamshire).

Infection and isotope incorporation. Chick embryo cells were inoculated at a density of 4 to $5 \times \mathrm{IO}^{4}$ cells $/ \mathrm{cm} .^{2}$ in $3.5 \mathrm{~cm}$. Petri dishes containing round coverslips of $3 \mathrm{~cm}$. diameter. The cells were cultivated in $2 \mathrm{ml}$. of culture medium at $37^{\circ}$ in an atmosphere of $95 \%$ air, $5 \% \mathrm{CO}_{2}$. For infection, 200 p.f.u./cell of u.v.-VSV were adsorbed to the cells at $37^{\circ}$ for $30 \mathrm{~min}$. Input multiplicities of virus are represented in terms of infectivity before u.v. irradiation.

After the cells were labelled by addition of appropriate radioactive precursors, the cells on coverslips were washed with $5 \%$ trichloracetic acid at 4 , and radioactivities on coverslips were determined using a Beckman liquid scintillation counter in $10 \mathrm{ml}$. of Bray's scintillator (Bray, I960).

Radioautography and cytological studies. After radioactivities were determined as mentioned above, coverslips were washed with $70 \%$ ethanol and used for radioautography or cytological observations. Radioautography was carried out using Kodak NTB 2 bulk emulsion according to the method of Kopriwa \& Leblond (1962). For the determination of mitotic index only, the cells were fixed with ethanol-acetic acid $(3: \mathrm{I}, \mathrm{v} / \mathrm{v})$ at room temperature for $30 \mathrm{~min}$., and stained with Giemsa dye. Labelled cell and mitotic indices were obtained by counting more than 20 areas of the grid square $\left(0.0625 \mathrm{~mm} .^{2}\right)$ of an ocular micrometer. Cells from late prophase to late telophase were counted for the determination of mitotic index. All results are presented as mean values for two dishes.

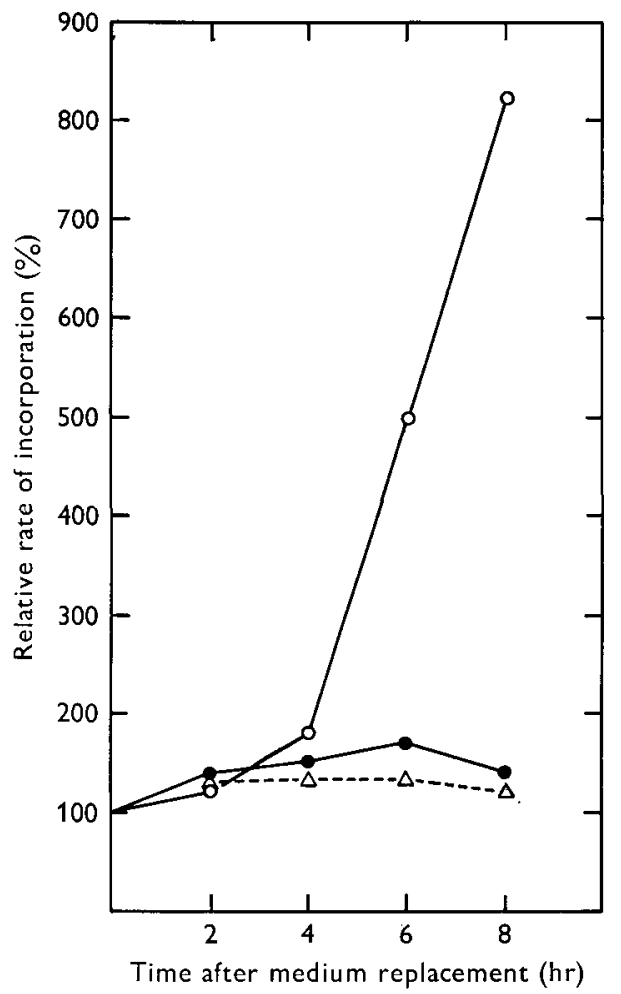

Fig. I. Macromolecular synthesis in chick embryo cells following medium replacement. The uptake of radioactive compounds by the cells is expressed as $\%$ of initial values. $0-0$, DNA;

$\longrightarrow$, RNA; $\triangle---\triangle$, protein. 


\section{RESULTS}

Pattern of macromolecular syntheses after medium replacement.

When chick embryo cells were seeded at a density of 4 to $5 \times 10^{4}$ cells $/ \mathrm{cm}$. ${ }^{2}$ with plating efficiency of about 40 to $50 \%$, the cell number increased exponentially for 2 to 3 days up to I to $\mathrm{I} \cdot 5 \times \mathrm{IO}^{5} \mathrm{cells} / \mathrm{cm}^{2}$.; growth ceased almost completely thereafter. The rate of DNA synthesis was at its maximum on the first day and then decreased rapidly. At the fourth day, when DNA

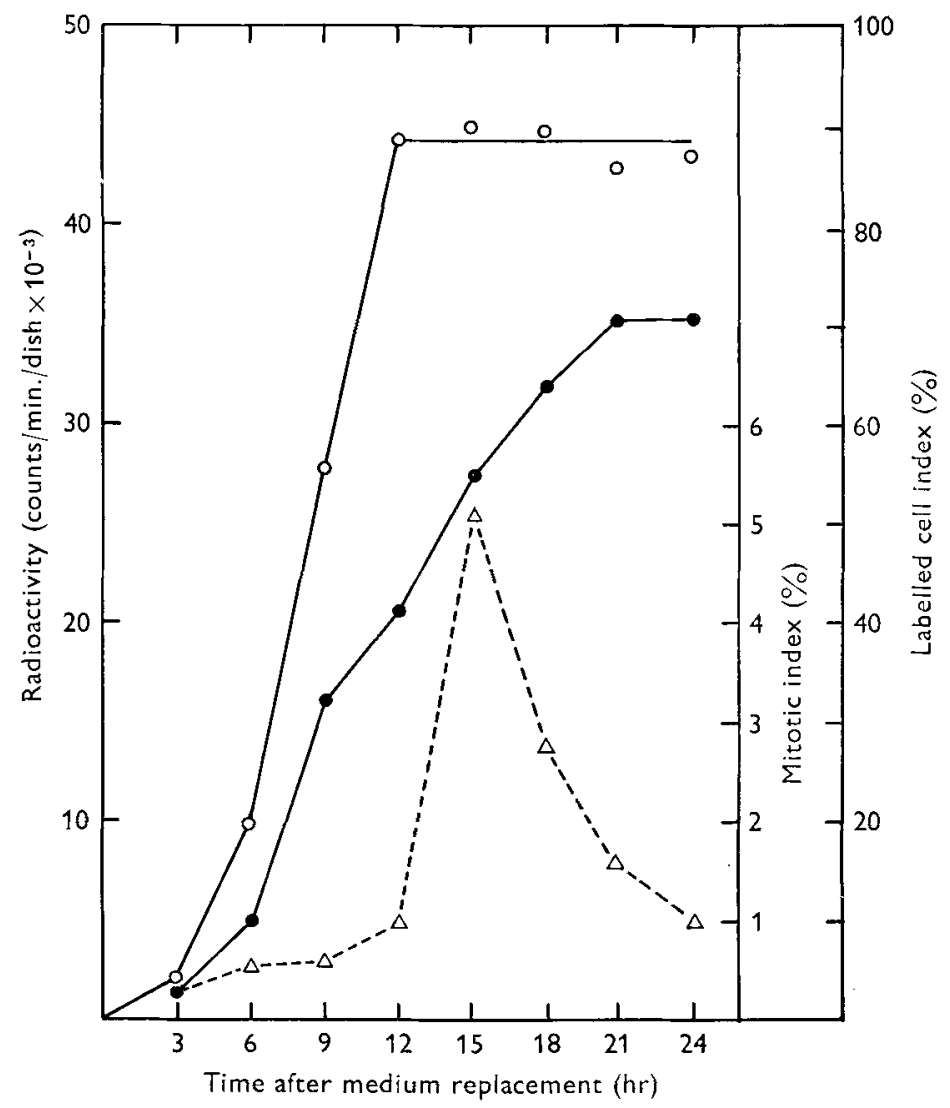

Fig. 2. DNA synthesis and mitosis following medium replacement.

$O$, radioactivity; $\bullet$, labelled cell index; $\Delta$, mitotic index.

synthesis was at its minimum, the spent culture medium was replaced and the cells were pulse-labelled at various times with ${ }^{14} \mathrm{C}$-labelled thymidine, uridine or amino acids. The characteristic changes in the pattern of macromolecular synthesis following medium replacement are shown in Fig. I. The synthetic of RNA and protein was stimulated by about $40 \%$ within $2 \mathrm{hr}$ and the increased levels were maintained thereafter. In sharp contrast, the rate of DNA synthesis increased rapidly, after a lag period of $4 \mathrm{hr}$, to up to about 10 times the rate at $8 \mathrm{hr}$ after medium replacement.

To examine the nature of the DNA synthesis induced by medium replacement, $\left[{ }^{3} \mathrm{H}\right]$ thymidine was added at the time of medium replacement and the cells were labelled continuously during further incubation. The cells were fixed with $5 \%$ trichloroacetic acid at various times to determine radioactivity, number of labelled cells and mitotic indices (Fig. 2). A sharp 
increase in the incorporation of radioactive thymidine was observed during 4 to $\mathrm{I} 2 \mathrm{hr}$, and there was no increase thereafter. A peak of mitotic index was found at 15 to I $8 \mathrm{hr}$. The initial increase in the number of labelled cells was paralleled by that in radioactivity. The increase in labelled cells during $\mathrm{I} 2$ to $24 \mathrm{hr}$ was probably due to division; the labelled cell index reached about $70 \%$ at $24 \mathrm{hr}$. These results indicate that onset of synchronized DNA synthesis was induced by medium replacement. Calculated from the final labelled cell index, about $55 \%$ of the cell population entered DNA synthesis synchronously.

Table I. Effect of type and concentration of serum on cellular DNA synthesis.

Condition

Control, culture medium not changed Eagle's minimal essential medium Eagle's $+5 \%$ calf serum Eagle's $+10 \%$ calf serum Eagle's $+10 \%$ foetal bovine serum $\left[{ }^{3} \mathrm{H}\right]$ thymidine uptake during $24 \mathrm{hr}$ (Counts/min./dish)

$\begin{array}{rr}356 & 39 \mathrm{I} \\ 734 & 87 \mathrm{I} \\ 2494 & 2697 \\ 3740 & 2879 \\ 3826 & 39 \mathrm{I} 2\end{array}$
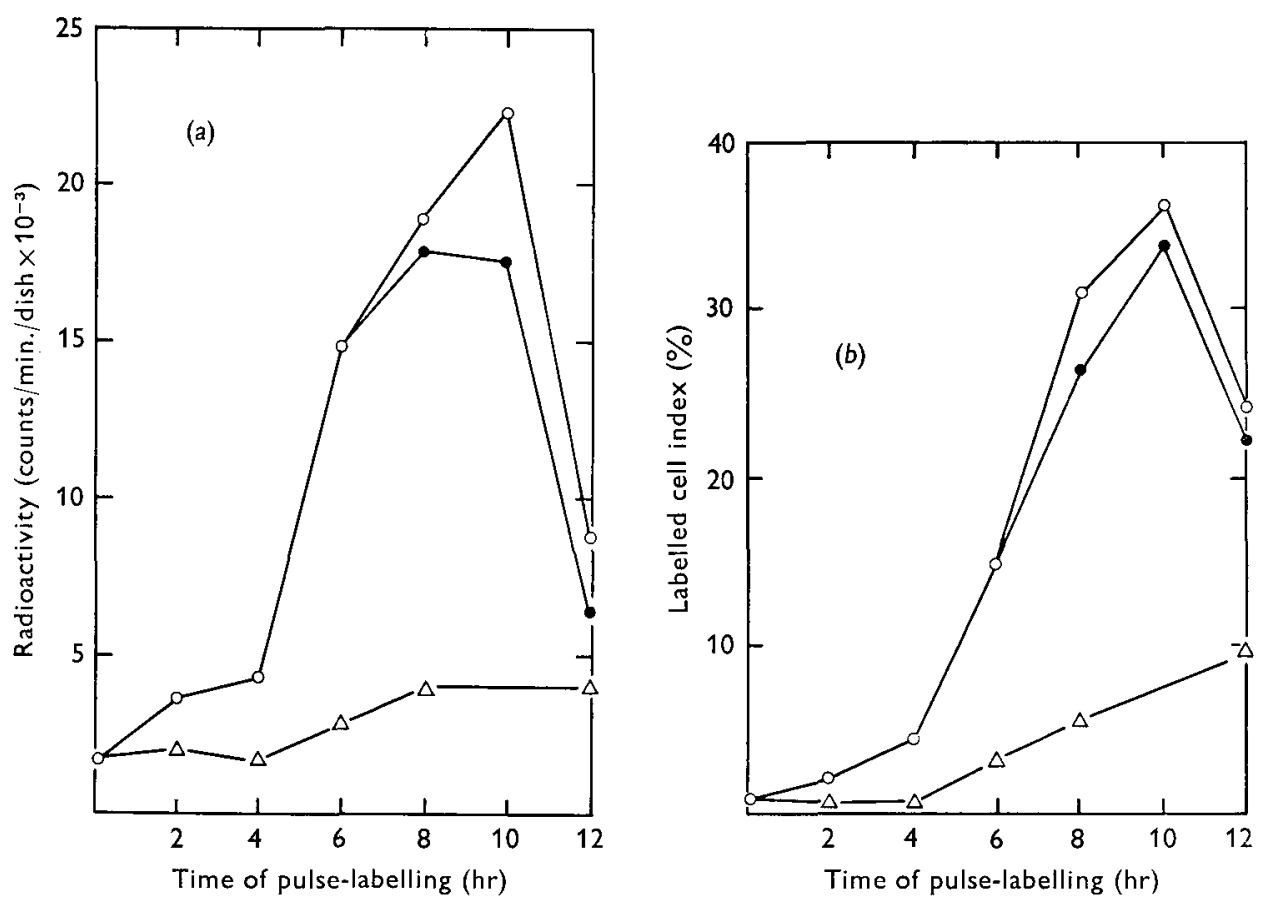

Fig. $3 a, b$. Effect of infection with u.v.-VSV on cellular DNA synthesis. $\mathrm{O}_{-} \mathrm{O}$, control; $\triangle \longrightarrow \triangle$, infected at o hr;

, infected at $6 \mathrm{hr}$.

To examine which component in the fresh medium was responsible for the induction of cellular DNA synthesis, culture medium on 4 day monolayers was replaced with Eagle's minimal essential medium containing different concentrations of calf serum or foetal bovine serum. At the time of medium replacement, $\left[{ }^{3} \mathrm{H}\right]$ thymidine was added and the cells were fixed after $24 \mathrm{hr}$. As shown in Table I, cellular DNA synthesis depended upon the type and concentration of serum, and the maximum incorporation of thymidine was obtained 
with medium containing $10 \%$ foetal bovine serum when $80 \%$ of cells were labelled with $\left[{ }^{3} \mathrm{H}\right]$ thymidine within $24 \mathrm{hr}$.

Effect of infection with u.v.-VSV on cellular DNA synthesis.

Culture medium on 4-day monolayers was replaced, and the cells infected with 200 p.f.u./ cell of u.v.-VSV at the same time or $6 \mathrm{hr}$ later. Control and infected cells were pulse-labelled with $\left[{ }^{3} \mathrm{H}\right]$ thymidine at different times to determine the rate of DNA synthesis (Fig. $3 a$ ) and the percentage of cells synthesizing DNA (Fig. $3 b$ ). The onset of DNA synthesis was prevented when the cells were infected at initially (Fig. $3 a$ ). If the cells were infected at $6 \mathrm{hr}$

Table 2. DNA synthesis in cells infected with u.v.-VSV at various times after medium replacement*.

\begin{tabular}{lcc} 
Time of infection & Counts/min./dish & $\begin{array}{c}\text { Labelled cell } \\
\text { index }(\%)\end{array}$ \\
Control, not infected & 7002 & $39 \cdot 0$ \\
\multirow{2}{*}{$2 \mathrm{hr}$} & 6556 & $34 \cdot 0$ \\
& 2345 & $10 \cdot 5$ \\
$4 \mathrm{hr}$ & 2545 & $14 \cdot 7$ \\
& 2447 & 15.9 \\
& 2496 & $21 \cdot 8$ \\
& 4428 & $29 \cdot 6$ \\
& 4026 & 26.5
\end{tabular}

* The cells were infected with 200 p.f.u./cell of u.v.-VSV at 2,4 or $6 \mathrm{hr}$ after the medium replacement, and pulse-labelled at $10 \mathrm{hr}$ with $0.2 \mu \mathrm{C}\left[{ }^{3} \mathrm{H}\right]$ thymidine/dish for $20 \mathrm{~min}$.

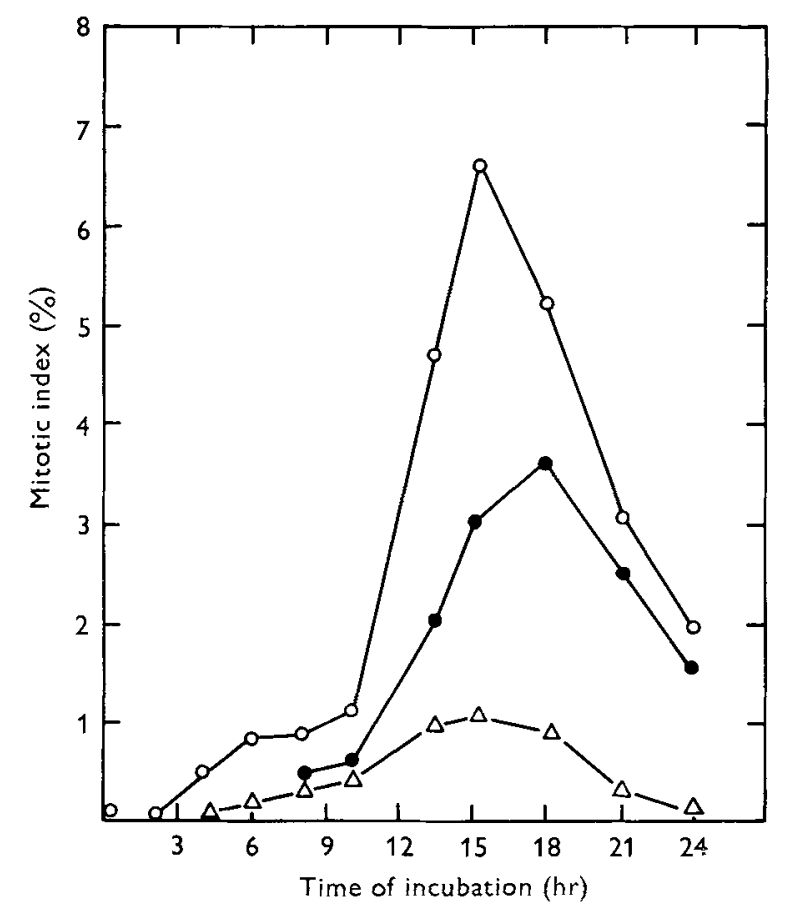

Fig. 4. Mitotic activity of chick embryo cells infected with u.v.-VSV. O- -0 , control; $\triangle-\triangle$, infected at o $\mathrm{hr}$; 
during the $\mathrm{S}$ phase, the rate of ongoing DNA synthesis was not reduced significantly (Fig. $3 a$ ). Furthermore, the onset of DNA synthesis was not inhibited within $4 \mathrm{hr}$ in cells infected at 6 hr (Fig. $3 b$ ).

The rate of DNA synthesis in cells infected with u.v.-VSV at various times after medium replacement is shown in Table 2 . The cells were infected at 2,4 or $6 \mathrm{hr}$ after medium replacement and pulse-labelled for $20 \mathrm{~min}$. with $\left[{ }^{3} \mathrm{H}\right]$ thymidine at $\mathrm{Io} \mathrm{hr}$, DNA synthesis was at a maximum at ro hr. As shown in Table 2, entry of the cells into DNA synthesis was inhibited by about $70 \%$ if the cells were infected at $2 \mathrm{hr}$. About $75 \%$ of the cells entered DNA synthesis if infected at $6 \mathrm{hr}$.

\section{Effect of infection with $u . v .-V S V$ on mitotic activity.}

The cells were infected with 200 p.f.u./cell of u.v.-VSV at the time of medium replacement or at $6 \mathrm{hr}$, and the mitotic index was determined at different times (Fig. 4). About $75 \%$ of the cells entered into DNA synthesis when infected at $6 \mathrm{hr}$ (Table 2). The mitotic index of cells infected at zero time was very low throughout the experimental period. In contrast, a peak of mitotic index was found at I 5 to I $8 \mathrm{hr}$ for cells infected at $6 \mathrm{hr}$.

\section{DISCUSSION}

Our previous investigation showed that cellular DNA synthesis was inhibited by infection with u.v.-inactivated VSV (Yaoi et al. 1970a). It was suggested that inhibition was due to the prevention of the onset of DNA synthesis rather than due to inhibition of the ongoing DNA replication. However, it was difficult to distinguish between the two possibilities, since the previous studies were performed on randomly growing cells. In the present study, the distinction between the prevention of the onset of DNA synthesis and the inhibition of the ongoing DNA replication was achieved by infecting the synchronized cells with u.v.inactivated VSV at various stages in the cell cycle.

DNA synthesis and cell division were initiated in chick embryo cells by replacing the culture medium. Under the conditions used, the cells entered into DNA synthesis about $4 \mathrm{hr}$ after medium replacement and the $\mathrm{S}$ phase lasted approximately $8 \mathrm{hr}$. The cells divided at $\mathrm{I} 5$ to $\mathrm{I} 8 \mathrm{hr}$. These results indicate that almost all cells are arrested in the G I phase in stationary cultures. The induction of DNA synthesis was influenced by type and concentration of serum in the fresh medium. A similar induction of DNA synthesis and cell division following medium replacement or serum addition was reported by Todaro, Lazer \& Green (1965) for $3 \mathrm{~T}_{3}$ cells and by Gurney (I969) for cultured chick embryo cells.

The onset of DNA synthesis was prevented by u.v.-inactivated VSV when the cells were infected at the time of medium replacement. Entry of cells into DNA synthesis was inhibited most effectively if the cells were infected more than $4 \mathrm{hr}$ before the onset of DNA synthesis. On the contrary, ongoing DNA replication was not inhibited significantly, and a majority of cells divided once they had entered DNA synthesis. These results indicate a selective inhibition by u.v.-inactivated VSV of the flow of $\mathrm{G}$ I cells into the $S$ phase.

Many DNA- or RNA-containing viruses are known to inhibit cellular DNA synthesis in infected cells (Martin \& Kerr, 1968). However, in most cases these inhibitory effects have been poorly characterized. Hodge \& Sharff (1969) studied the inhibitory effect of adenovirus type 2 infection on DNA synthesis in synchronized HeLa cells and reported that when virus DNA replication started during G I phase, the subsequent onset of cellular DNA synthesis was prevented. On the other hand, when virus DNA synthesis began after the onset of $S$ phase, cellular DNA replication was not inhibited completely.

The mechanism of the selective inhibition of the onset of cellular DNA synthesis by u.v.- 
inactivated VSV differs from that of adenovirus infection. Firstly, replication of VSV is restricted to the cytoplasm of infected cells (Yaoi, Amano \& Mitsui, 1970 b), while adenovirus multiplies in the cell nucleus. Secondly, no replication of virus is required for the inhibition of cellular DNA synthesis by VSV(Yaoi et al. 1970 a), whereas virus DNA replication is necessary for the inhibition of cellular DNA synthesis by adenovirus 2. Thirdly, adenovirus 2, but not VSV, reduced the ongoing DNA replication to about $50 \%$. Thus, the selective inhibition of the initiation of cellular DNA synthesis by u.v.-inactivated VSV is unique and appears to be extremely suitable for studies of virus-cell interactions and of the mechanism of the initiation of DNA synthesis in animal cells.

\section{REFERENCES}

BRAY, G. A. (I960). A simple efficient scintillator for counting aqueous solutions in a liquid scintillation counter. Analytical Biochemistry 1, 279.

GURNEY, T. JUN., ( 1969 ). Local stimulation of growth in primary cultures of chick embryo fibroblasts. Proceedings of the National Academy of Sciences of the United States of America 62, 906.

HODGE, L. D. \& SCHARFF, M. D. (1969). Effect of adenovirus on host cell DNA synthesis in synchronized cells. Virology 37, 554.

KOPRIWA, B. M. \& LEBLOND, C. P. (1962). Improvement on the coating technique of radioautography. Journal of Histochemistry and Cytochemistry ro, 269.

MARTIN, E. M. \& KERR, I. M. (I968). In The Molecular Biology of Viruses. I 8th Symposium of the Society of General Microbiology, Ed. by L. V. Crawford \& M. G. P. Stoker, p. I5. London, Cambridge University Press.

TODARO, G. H., LAZER, G. K. \& GREEN, H. (I965). The initiation of cell division in a contact-inhibited mammalian cell line. Journal of Cellular and Comparative Physiology 66, 325.

YAOI, Y., MITSUI, H. \& AMANO, M. (I970a). Effect of u.v. irradiated vesicular stomatitis virus on nucleic acid synthesis in chick embryo cells. Journal of General Virology 8, I65.

YAOI, Y., AMANO, M. \& MITSUI, H. (I970 $b$ ). Intracellular site of RNA replication of vesicular stomatitis virus as revealed by radioautography. Japanese Journal of Microbiology (In the Press).

(Received I3 April I970) 